\title{
Ketepatan Waktu Pelaporan Keuangan: Sistem Pengendalian Internal dan Sistem Informasi Pengelolaan Keuangan Daerah
}

\author{
Alwina Noviani", Decky Hendarsyah* \\ "Sekolah Tinggi Ilmu Ekonomi (STIE) Syariah Bengkalis, Riau, Indonesia \\ E-mail: alwinanoviani.an@gmail.com; deckydb@gmail.com
}

\begin{abstract}
Abstrak
Laporan keuangan merupakan informasi yang bermanfaat dalam mengambil sebuah keputusan. Informasi yang relevan, akurat dan handal dipengaruhi oleh ketepatan waktu dalam penyajian informasi itu sendiri. Tujuan penelitian ini adalah untuk melengkapi kekurangan studi yang ada, kemudian menganalisa sejauh mana dan sebesar apa sistem pengendalian internal (SPI) dan sistem informasi pengelolaan keuangan daerah (SIPKD) dalam mempengaruhi ketepatan waktu pelaporan keuangan (KWPK) baik secara parsial maupun simultan pada Dinas Perhubungan Kabupaten Bengkalis. Penelitian ini adalah deskriptif kuantitatif, sumber data yang dipakai adalah data primer dan sekunder. Dalam mengumpulkan data penelitian digunakan kuesioner dan studi pustaka. Data dianalisis dengan teknik regresi linear berganda. Penelitian ini menunjukkan bahwa secara parsial dan simultan SPI dan SIPKD memiliki pengaruh signifikan terhadap KWPK pada Dinas Perhubungan Kabupaten Bengkalis.
\end{abstract}

Kata Kunci: SPI, SIPKD, Ketepatan Waktu, Laporan Keuangan.

\begin{abstract}
Financial reports are useful information in making a decision. Relevant, accurate and reliable information is influenced by the timeliness of presenting the information itself. The aim of this study is to complement the shortcomings of existing studies, then to analyze the extent and extent of the internal control system (ICS) and regional financial management information systems (RFMIS) in influencing the timeliness of financial reporting (TFR) either partially or simultaneously at the Bengkalis Regency Transportation Office. This research is descriptive quantitative, where the data sources used are primary and secondary data. In collecting research data used questionnaires and literature study. The data were analyzed using multiple linear regression techniques. This study shows that partially and simultaneously the ICS and the RFMIS had a significant influence on the TFR at the Bengkalis Department of Transportation.
\end{abstract}

Keywords: ICS, RFMIS, Timeliness, Financial Reports.

\section{Pendahuluan}

Laporan keuangan sektor publik merupakan cerminan posisi keuangan dari semua transaksi yang pernah dilakukan oleh suatu organisasi publik [1]. Pemerintah daerah sebagai pelayan publik dituntut supaya dapat mengelola keuangan daerah secara baik dan profesional dalam mewujudkan pemerintah yang bersih. Pengelolaan keuangan daerah yang baik merupakan kemampuan dalam mengontrol kebijakan dalam penggunaan keuangan di daerah secara efektif, efisien, transparan, tepat waktu dan akuntabel. Setiap Organisasi Perangkat Daerah (OPD) harus menyajikan laporan keuangan. Supaya penyajian laporan keuangan oleh OPD sejalan dengan Standar Akuntansi Pemerintahan (SAP), maka pemerintah daerah harus melakukan pembinaan dalam kerangka sistem pengendalian internal (SPI). Pembinaan dapat dilakukan dengan cara menerapkan sistem informasi pengelolaan keuangan daerah (SIPKD) terhadap kepala OPD beserta entitas OPD. Tujuan dari pembinaan tersebut, supaya laporan keuangan yang dihasilkan OPD sesuai dengan yang diharapkan. Perpaduan seluruh laporan keuangan dari OPD yang ada akan menjadi laporan keuangan bagi Pemerintah Daerah. Tujuan Pemerintah dalam menghasilkan laporan keuangan agar dapat menyajikan informasi yang akuntabel, tepat waktu dan akurat serta dapat dimanfaatkan oleh pihak lain dalam menilai akuntabilitas, kinerja dan keputusan pemerintah seperti dalam ekonomi, sosial, maupun politik [2,3].

Sejauh ini penelitian tentang SPI yang berhubungan dengan laporan keuangan terdapat beberapa aspek. Pertama, penelitian yang melihat pengaruh antara SPI dengan aspek kualitas laporan keuangan $[4,5,6,7,8,9,10,11,12,13]$. Kedua, 
penelitian yang melihat pengaruh antara SPI dengan aspek akuntabilitas laporan keuangan [14]. Ketiga, penelitian yang melihat pengaruh antara SPI dengan sistem informasi akuntansi (SIA) $[15,16]$. Kemudian penelitian tentang SIPKD yang berhubungan dengan beberapa aspek. Pertama, penelitian yang melihat pengaruh antara SIPKD dengan kualitas laporan keuangan [17, 18]. Kedua, penelitian yang melihat pengaruh antara SIPKD dengan kinerja pegawai [19]. Ketiga, penelitian yang melihat pengaruh antara SIPKD dengan kepuasan pengguna [20]. Keempat, penelitian yang membahas pemanfaatan dan faktor-faktor yang mempengaruhi SIPKD [21,22]. Selanjutnya penelitian mengenai ketepatan waktu pelaporan keuangan (KWPK) yang berhubungan dengan faktor-faktor selain SPI dan SIPKD [3, 23,24, $25,26,27,28]$.

Penelitian ini bertujuan untuk melengkapi kekurangan dari penelitian yang sudah ada karena masih ada celah penelitian tentang ketepatan waktu dalam pelaporan keuangan (KWPK) yang dihubungkan dengan SPI dan SIPKD, baik secara parsial maupun simultan. Selain itu juga bertujuan untuk menganalisa pengaruh SPI terhadap KWPK secara parsial dan menganalisa pengaruh SIPKD terhadap KWPK secara parsial serta menganalisa pengaruh SPI dan SIPKD terhadap KWPK secara simultan pada Dinas Perhubungan Kabupaten Bengkalis.

Penelitian ini didasarkan pada kenyataan dilapangan bahwa SPI dan SIPKD dapat mempengaruhi KWPK. Hal ini disebabkan terdapatnya komponen SPI dan komponen SIPKD dalam kegiatan pelaporan keuangan. Dengan adanya komponen tersebut maka laporan keuangan bisa diselesaikan dengan baik dan disajikan tepat pada waktunya sehingga dapat dimanfaatkan oleh pihak-pihak terkait serta publik.

\section{Telaah Literatur Dan Hipotesis}

\section{Sistem Pengendalian Internal (SPI)}

Pengendalian internal merupakan prosedur dan kebijakan untuk menjaga agar aktiva bebas dari penyelewengan dan memastikan bahwa informasi yang diberikan akurat serta telah mengikuti hukum atau peraturan yang ada [29]. Pengendalian internal dapat melindungi aktiva pada lokasi yang tidak tepat, karena ada informasi yang akurat. Keakuratan informasi sangat dibutuhkan untuk pencapaian keberhasilan tujuan dan dapat mencegah terjadinya penyalahgunaan aktiva [30]. Pengendalian internal merupakan salah satu fondasi terkuat dari pemerintahan yang baik [6].

Menurut Rai bahwa SPI adalah prosedur dan kebijakan yang dibuat untuk memberikan kepastian bagi pengelola organisasi bahwa tujuan dan sasaran organisasi tercapai $[31,5]$. SPI terdiri dari lima unsur atau komponen termasuk didalamnya pengendalian aplikasi yang terdapat pada komponen kegiatan pengendalian atas pengelolaan sistem informasi [32].

Penelitian yang mengemukakan bahwa SPI memiliki pengaruh yang signifikan atas kualitas laporan keuangan diteliti oleh [4, 5 7, 8, 9, 11, 12, 13]. Berikut terdapat hasil penelitian yang mengemukakan bahwa SPI tidak mempunyai pengaruh atas kualitas laporan keuangan, diteliti oleh [6, 10]. Kemudian terdapat juga penelitian yang mengemukakan bahwa SPI tidak mempunyai pengaruh atas akuntabilitas laporan keuangan, diteliti oleh [14]. Kemudian ada juga penelitian yang menemukan bahwa SPI berpengaruh positif atau signifikan terhadap SIA atau sebaliknya yang dilakukan oleh $[15,16]$. Penelitian mengenai pengaruh SPI terhadap KWPK belum ditemukan, oleh sebab itu diambil penelitian-penelitian yang meneliti SPI sebagai variabel independent. Dari beberapa hasil penelitian tersebut mayoritas SPI sebagai variabel independent berpengaruh positif terhadap variabel dependentnya, oleh sebab itu dapat dibentuk hipotesis pertama (H1): SPI berpengaruh signifikan terhadap KWPK pada Dinas Perhubungan Kabupaten Bengkalis.

\section{Sistem Informasi Pengelolaan Keuangan Daerah (SIPKD)}

SIPKD adalah suatu perangkat lunak aplikasi yang dirancang dan dibuat oleh Kementerian Dalam Negeri. Tujuan dibangunnya SIPKD adalah untuk efektifitas, efisiensi dalam penghimpunan data dan percepatan pengiriman data keuangan daerah serta penerapan regulasi dalam bidang pengelolaan keuangan daerah [33].

SIPKD merupakan wujud nyata dalam pengelolaan keuangan daerah yang dibangun Kementerian Dalam Negeri untuk pemerintah provinsi dan kabupaten/kota di Indonesia [33]. Selain itu SIPKD bertujuan untuk persamaan persepsi dan penguatan sistem serta prosedur dalam mengelola keuangan daerah yang selaras dengan implementasi berbagai peraturan perundang-undangan [34].

Penelitian yang mengemukakan bahwa SIPKD mempunyai pengaruh positif terhadap kualitas laporan keuangan diteliti oleh $[17,18]$. Kemudian penelitian yang mengemukakan bahwa SIPKD memiliki pengaruh positif atas kinerja pegawai dilakukan oleh [19]. Terdapat juga penelitian yang menemukan bahwa SIPKD berpengaruh positif atau signifikan terhadap kepuasan pengguna dilakukan oleh [20]. Kemudian terdapat penelitian yang mengemukakan bahwa semua variabel independentnya memiliki pengaruh positif terhadap minat pemanfaatan SIPKD, ini diteliti oleh [21]. Kemudian ada juga penelitian yang mengemukakan bahwa lebih kurang 36 persen variabel 
independent dari aspek pengguna sistem memiliki pengaruh signifikan atas perilaku dalam memanfaatkan SIPKD, ini diteliti oleh [22]. Penelitian mengenai pengaruh SIPKD terhadap KWPK juga belum ditemukan, oleh sebab itu diambil penelitian-penelitian yang meneliti SIPKD sebagai variabel independent dan dependent. Dari hasil penelitian tersebut mayoritas SIPKD berpengaruh positif baik sebagai variabel dependent maupun independent oleh sebab itu dapat dibentuk hipotesis kedua (H2): SIPKD berpengaruh signifikan terhadap KWPK pada Dinas Perhubungan Kabupaten Bengkalis.

\section{Ketepatan Waktu Pelaporan Keuangan (KWPK)}

Laporan keuangan sektor pemerintahan berfungsi untuk memberikan informasi relevan tentang posisi keuangan dari seluruh transaksi selama satu periode, hal tersebut dinyatakan dalam SAP [35]. Laporan keuangan pemerintahan harus dipublikasikan tepat pada waktunya. Maksud tepat waktu disini adalah laporan tersebut disajikan pada tempo yang tepat bagi para pembuat keputusan dalam memutuskan suatu keputusan [36]. KWPK merupakan jarak waktu untuk menyajikan laporan keuangan dalam satu tahun melalui audit yang diumumkan kepada publik tertanggal pada tutup buku [3]. Informasi laporan keuangan yang disajikan akan hilang relevansinya apabila terdapat penundaan waktu dalam pelaporannya [37]. Laporan keuangan harus memberikan informasi yang bermanfaat. Salah satu bentuk laporan keuangan yang bermanfaat adalah mampu menyajikan informasi tepat pada waktunya. Namun semakin besar volume data yang ditangani, biasanya kecepatan dalam pengolahan data akan menurun. Padahal pembuat keputusan selalu membutuhkan informasi yang tepat waktu. Jika pengolahan data dilaksanakan secara manual, maka ketidakpastian akan semakin besar. Hal ini sesuai dengan kapasitas manusia, bilamana suatu pekerjaan dilakukan dengan cepat, kecermatannya akan semakin menurun [38]. Informasi yang relevan dan tersedia dalam waktu yang lebih cepat, maka akan mampu meningkatkan kapasitasnya dalam pengambilan suatu keputusan [3].

Penelitian yang mengemukakan bahwa struktur kepemilikan dan profitabilitas memiliki pengaruh positif atas KWPK dilakukan oleh [23]. Kemudian penelitian yang mengemukakan bahwa variabel independennya memiliki pengaruh positif terhadap KWPK diteliti oleh [24]. Terdapat juga penelitian yang mengemukakan bahwa pergantian auditor mempunyai pengaruh positif atas KWPK dilakukan oleh [26]. Kemudian ada juga penelitian yang menunjukkan bahwa variabel independennya secara simultan memiliki pengaruh posistif terhadap KWPK diteliti oleh $[3,25,28]$. Kemudian penelitian yang mengemukakan bahwa pemanfaatan teknologi informasi memiliki pengaruh signifikan atas KWPK dilakukan oleh [27]. Penelitian mengenai pengaruh SPI dan SIPKD terhadap KWPK juga belum ditemukan, oleh sebab itu diambil penelitian-penelitian yang meneliti KWPK sebagai variabel dependent. Dimana penelitian-penelitian tersebut menggambarkan bahwa variabel independent memberikan pengaruh terhadap KWPK variabel dependent. Oleh sebab itu dapat dibentuk hipotesis ketiga (H3): SPI dan SIPKD berpengaruh signifikan terhadap KWPK pada Dinas Perhubungan Kabupaten Bengkalis.

\section{Metode Penelitian}

Penelitian ini didesain menggunakan metode deskriptif kuantitatif, dimana sumber data yang dipakai adalah data primer dan sekunder. Penelitian ini dilaksanakan pada Dinas Perhubungan Kabupaten Bengkalis. Semua pegawai yang terdapat pada Dinas Perhubungan Kabupaten Bengkalis menjadi populasi dalam penelitian ini. Sedangkan teknik dalam mengambil sampel menggunakan metode purposive sampling, tujuannya supaya sampel berkenaan langsung dengan beberapa orang yang memegang kepentingan dan berhubungan langsung dengan pelaporan keuangan serta pegawai yang bertugas menggunakan SIPKD yang termasuk pada sub bagian keuangan dan perlengkapan yang ada pada Dinas Perhubungan Kabupaten Bengkalis. Bagian keuangan terdiri dari 23 orang dan bagian perlengkapan 7 orang (termasuk didalamnya 9 orang pengguna SIPKD). Sehingga jumlah sampel yang didapat adalah sebanyak 30 orang. Dalam mengumpulkan data pada penelitian ini digunakan teknik kuesioner dan studi pustaka. Kemudian analisis data menggunakan metode regresi linier berganda. Dalam mengolah data digunakan alat bantu yaitu berupa software SPSS.

\section{Hasil Penelitian}

\section{Data Responden}

Berdasarkan data yang telah disebarkan melalui kuesioner pada Dinas Perhubungan Kabupaten Bengkalis diperoleh data responden sebanyak 30 orang yang diklasifikasi berdasarkan jenis kelamin, umur dan status pegawai. Berdasarkan jenis kelamin, laki-laki berjumlah 10 orang (33\%), perempuan 20 orang (67\%). Berdasarkan rentang umur, 18-30 tahun berjumlah 3 orang (10\%), 31-40 tahun berjumlah 7 orang (23\%), 41-50 tahun berjumlah 15 orang $(50 \%), 51$ tahun keatas berjumlah 5 orang $(17 \%)$. Sedangkan berdasarkan status pegawai, PNS berjumlah 20 orang (67\%) dan honorer berjumlah 10 orang (33\%).

\section{Validitas Data}

Berdasarkan data kuesioner maka dapat diketahui nilai signifikan $(\alpha)$ yaitu $0,05, \mathrm{n}$ sebesar 30 sehingga $\mathrm{df}$ $($ derajat kebebasan $)=(n-2)=(30-2)=28$. Dari nilai tersebut dapat ditarik nilai $r_{\text {tabel }}$ menggunakan tabel $r$ 
yaitu 0,361. Dalam mengambil keputusan validitas terdapat syaratnya yaitu: jika $r_{\text {hitung }}>r_{\text {tabel }}$ maka data dinyatakan valid, sebaliknya tidak valid (Siregar 2013, 47). Setelah data kuesioner diolah menggunakan SPSS

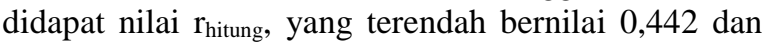
yang tertinggi bernilai 0,904. Sehingga dari keseluruhan nilai tersebut $r_{\text {hitung }}>r_{\text {tabel }}$, maka dapat dikatakan semua hasil kuesioner valid.

\section{Reliabilitas}

Keputusan reliable pada reliabilitas dapat diambil jika cronbach's alpha > 0,6 sebaliknya tidak reliable (Yusuf 2014, 241). Berdasarkan data kuesioner yang telah diolah menggunakan SPSS didapat nilai cronbach's alpha 0,961, dimana 0,961 > 0,6, sehingga dapat dikatakan bahwa keseluruhan hasil kuesioner reliable.

\section{Normalitas}

Normalitas diuji menggunakan kolmogorovsmirnov test. Uji normalitas dapat diputuskan, jika nilai signifikan > 0,05 maka keputusannya adalah data memiliki distribusi normal, sebaliknya tidak memiliki distribusi normal (Yusuf 2014, 243). Dari pengujian kolmogorov-smirnov dari output SPSS didapat nilai signifikan (Asymp. Sig.) 0,200, artinya 0,200>0,05, maka dapat diputuskan bahwa data memiliki distribusi normal.

\section{Regresi Linear Berganda}

\begin{tabular}{lc}
\multicolumn{2}{c}{ Tabel 1 Coefficients } \\
\hline \multicolumn{1}{c}{ Variabel } & Nilai $\boldsymbol{\alpha} / \boldsymbol{\beta}$ \\
\hline (Constant) & 0,613 \\
SPI & 0,077 \\
SIPKD & 0,120 \\
\hline Sumber: olahan output SPSS &
\end{tabular}

Adapun persamaan regresi linier berganda antara SPI dan SIPKD dengan KWPK dari Tabel 1 adalah: Y $=\alpha+\beta 1 X 1+\beta 2 X 2 ; Y=0,613+0,077 X 1+0,120 X 2$, maka bisa dijabarkan bahwa nilai $\alpha$ sebagai nilai konstan yaitu sebesar 0,613 , yang berarti jika tidak terdapat SPI dan SIPKD sebagai variabel bebas, maka nilai KWPK sebesar 0,613 . Nilai $\beta 1$ sebagai koefisien pada variabel SPI sebesar 0,077, artinya setiap penambahan 1 satuan variabel SPI, maka besarnya variabel KWPK akan bertambah sebesar 0,077. Nilai $\beta 2$ sebagai koefisien pada variabel SPKD sebesar 0,120 , artinya setiap penambahan 1 satuan variabel SIPKD, maka besarnya variabel KWPK akan bertambah sebesar 0,120 .

\section{Hipotesis}

Tabel 2 Hasil Hipotesis

\begin{tabular}{llcc}
\hline & \multicolumn{1}{c}{ Hipotesis } & t/f & Sig. \\
\hline H1 & SPI $\rightarrow$ KWPK & 10,633 & 0,000 \\
H2 & SIPKD $\rightarrow$ KWPK & 10,649 & 0,000 \\
H3 & SPI * SIPKD $\rightarrow$ KWPK & 57,058 & 0,000 \\
\hline $\boldsymbol{R}$ & & 0,899 & \\
$\boldsymbol{R}$ Square & 0,809 & \\
Adjusted $\boldsymbol{R}$ Square & 0,794 & \\
\hline
\end{tabular}

Sumber: olahan output SPSS

Pengujian hipotesis secara parsial perlu dicari nilai $\mathrm{t}_{\text {tabel }}$, dimana nilai $\alpha / 2=0,05 / 2=0,025$; $\mathrm{df}=\mathrm{n}-2=$ $30-2=28$, jika diambil pada tabel t maka diperoleh nilai tabel 0,683 . Kemudian dalam mengambil keputusan uji parsial adalah apabila $t_{\text {hitung }}>t_{\text {tabel }}$ atau sig. < 0,05 maka keputusan hipotesis adalah diterima, sebaliknya hipotesis ditolak (Yusuf 2014, 244). Dilihat dari Tabel 2 untuk variabel SPI $\rightarrow$ KWPK, dimana nilai $t_{\text {hitung }}$ adalah 10,633 dan sig. (signifikansi) sebesar 0,000 , berarti nilai $t_{\text {hitung }}>t_{\text {tabel }}(10,633>0,683)$ dan nilai sig. $<0,05(0,000<0,05)$ sehingga hipotesis pertama (H1) diterima. Sedangkan untuk variabel

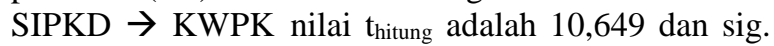
0,000 , berarti nilai $t_{\text {hitung }}>t_{\text {tabel }}(10,649>0,683)$ dan nilai sig. $<0,05(0,000<0,05)$ sehingga hipotesis kedua $(\mathrm{H} 2)$ diterima.

Kemudian pengujian hipotesis secara simultan perlu dicari nilai $\mathrm{f}_{\text {tabel }}$, dimana nilai Df1 sebesar 2, nilai Df2 sebesar 27, dengan taraf signifikan $(\alpha) 0,05$, jika dilihat pada tabel $\mathrm{f}$ maka diperoleh nilai $\mathrm{f}_{\text {tabel }}$ sebesar 3,35. Dasar dalam mengambil keputusan adalah jika $\mathrm{f}_{\text {hitung }}$ besar dari $\mathrm{f}_{\text {tabel }}$ atau sig. kecil dari 0,05 maka keputusan hipotesis adalah diterima, sebaliknya hipotesis ditolak (Yusuf 2014). Dilihat dari Tabel 2 untuk variabel SPI * SIPKD $\rightarrow$ KWPK nilai $\mathrm{f}_{\text {hitung }}$ sebesar 57,058 dan nilai sig sebesar 0,00 , berarti nilai $f_{\text {hitung }}>f_{\text {tabel }}(57,058>3,35)$ dan nilai sig. $<0,05(0,00$ $<0,05)$ sehingga hipotesis ketiga $(\mathrm{H} 3)$ diterima.

\section{Koefisien Determinasi}

Berdasarkan Tabel 2 dapat dilihat hasil koefisien determinasi, dimana diketahui bahwa korelasi (R) memiliki nilai 0,899 , artinya terjadi hubungan yang sangat kuat antara SPI dan SIPKD terhadap KWPK, karena nilai korelasi > 0,8 atau mendekati 1 (Sugiyono 2014). Kemudian secara simultan SPI dan SIPKD memiliki pengaruh terhadap KWPK, dimana besar pengaruhnya adalah $79,4 \%$. Besar persentase tersebut didapat dari nilai Adjusted $R$ Square yaitu 0,794.

\section{Pembahasan Penelitian}

\section{Hipotesis Pertama (H1)}

Dari hasil penelitian didapat H1 diterima, artinya SPI berpengaruh signifikan terhadap KWPK pada Dinas Perhubungan Kabupaten Bengkalis. Oleh sebab itu jika SPI diterapkan sebaik mungkin maka laporan keuangan dapat disajikan tepat pada waktunya, karena sesuai dengan prosedur dan peraturan yang ada. Sebaliknya jika SPI tidak diterapkan dengan baik maka akan berefek kurang baik terhadap kinerja pemerintah dimana terjadi keterlambatan penyajian laporan keuangan. Dinas Perhubungan Kabupaten Bengkalis telah melaksanakan SPI dalam membuat laporan keuangan, ini berdasarkan pada Peraturan Bupati Bengkalis Nomor 67 tahun 2016 [39] dan Peraturan

209 | Jurnal Akuntansi, Ekonomi dan Manajemen Bisnis | Vol. 8 No.2, December 2020, 206-213 | E-ISSN: 2548-9836 
Pemerintah RI Nomor 60 Tahun 2008 [32] dimana seluruh komponen SPI dilaksanakan dengan baik terutama pada sub komponen pengendalian aplikasi terdapat pengendalian mulai dari input data, proses data sampai output sehingga pelaporan keuangan dapat disajikan tepat pada waktunya.

Hasil hipotesis ini sejalan dengan hasil penelitian $[4,5,7,8,9,11,12,13,16]$ jika dilihat variabel SPI sebagai variabel independent, dimana SPI berpengaruh signifikan terhadap variabel dependent pada penelitian mereka masing-masing. Sedangkan hasil hipotesis ini tidak sejalan dengan penelitian $[6,10,14]$ jika dilihat variabel SPI sebagai variabel independent, dimana SPI tidak berpengaruh terhadap variabel dependent pada penelitian mereka masing-masing.

\section{Hipotesis Kedua (H2)}

Dari hasil penelitian didapat $\mathrm{H} 2$ diterima, artinya SIPKD berpengaruh signifikan terhadap KWPK pada Dinas Perhubungan Kabupaten Bengkalis. Oleh sebab itu jika SIPKD diterapkan sebaik mungkin maka penyajian laporan keuangan akan disajikan tepat pada waktunya, karena SIPKD dibangun bertujuan untuk efektifitas dan efesiensi pengelolaan keuangan daerah. Sebaliknya jika SIPKD tidak diterapkan dengan baik maka pelaporan keuangan akan terlambat penyajiannya. Dinas Perhubungan Kabupaten Bengkalis dalam menerapkan SIPKD berdasarkan Dokumen Pelaksanaan Anggaran dan Dokumen Pelaksanaan Pergeseran Anggaran Kabupaten Bengkalis serta Permendagri Nomor 13 Tahun 2006 [33]. Dimana komponen-komponen SIPKD dipenuhi dan dijalan dengan baik sehingga pelaporan keuangan dapat disajikan tepat pada waktunya.

Hasil hipotesis ini sejalan dengan hasil penelitian $[17,18,19,20,21,22]$ jika dilihat variabel SIPKD sebagai variabel independen, dimana SIPKD berpengaruh signifikan terhadap variabel dependen pada penelitian mereka masing-masing.

\section{Hipotesis Ketiga (H3)}

Dari hasil penelitian didapat $\mathrm{H} 3$ diterima, berarti bahwa SPI dan SIPKD mempunyai pengaruh signifikan terhadap KWPK pada Dinas Perhubungan Kabupaten Bengkalis. Oleh sebab itu jika SPI dan SIPKD diterapkan dengan baik maka pelaporan keuangan dapat disajikan tepat pada waktunya, sebaliknya jika SPI dan SIPKD tidak diterapkan dengan baik maka laporan keuangan tidak dapat disajikan tepat pada waktunya. Secara simultan besar pengaruh SPI dan SIPKD terhadap KWPK pada Dinas Perhubungan Kabupaten Bengkalis adalah 79,4\%. Dinas Perhubungan Kabupaten Bengkalis telah menerapkan SPI dan SIPKD dengan baik sejalan dengan komponen, prosedur dan ketentuan yang ada sehingga laporan keuangan dapat disajikan tepat pada waktunya dan berdampak positif pada pengambilan keputusan oleh pihak-pihak yang terkait

Hasil hipotesis ini sejalan dengan hasil penelitian $[3,23,24,25,26,27,28]$ jika dilihat variabel KWPK sebagai variabel dependen, dimana KWPK dipengaruhi secara signifikan oleh variabel independen pada penelitian mereka masing-masing.

\section{Kesimpulan dan Saran}

Ternyata KWPK yang dihubungkan dengan SPI dan SIPKD merupakan hal baru dan belum ada yang melakukan penelitian tersebut sehingga dapat menambah kekurangan studi yang ada. Kemudian dilihat dari hubungan, terdapat hubungan yang begitu kuat antara SPI dan SIPKD terhadap KWPK pada Dinas Perhubungan Kabupaten Bengkalis. Hal tersebut terbukti secara parsial bahwa penerapan SPI berpengaruh signifikan terhadap KWPK pada Dinas Perhubungan Kabupaten Bengkalis. Kemudian secara parsial penerapan SIPKD juga berpengaruh signifikan terhadap KWPK pada Dinas Perhubungan Kabupaten Bengkalis. Secara simultan ada pengaruh signifikan antara SPI dan SIPKD terhadap KWPK pada Dinas Perhubungan Kabupaten Bengkalis dengan besar pengaruh $79,4 \%$.

Karena keterbatasan penelitian ini maka diharapkan kepada peneliti lainnya untuk dapat meneliti faktor-faktor selain SPI dan SIPKD dimana masih terdapat ruang sebesar $20,6 \%$. Kemudian untuk Dinas Perhubungan Kabupaten Bengkalis diharapkan agar dapat menjaga konsistensi dan meningkatkan penerapan SPI dan SIPKD sehingga pelaporan keuangan tetap terjaga ketepatan waktu penyajiannya.

\section{Daftar Pustaka}

A. Nordiawan, Deddi. 2006. Akuntansi Sektor Publik. Jakarta: Salemba Empat.

B. Tunggal, Amin Widjaja. 2010. Dasar-Dasar Audit Internal Pedoman Untuk Auditor Baru. Jakarta: Harvarindo.

C. Rachmawi, Sella, Rini Rini, and Yessi Fitri. 2016. "Faktor-Faktor Yang Mempengaruhi Ketepatan Waktu Pelaporan Keuangan Pemerintah Daerah Di Indonesia." Akuntabilitas: Jurnal Ilmu

$\begin{array}{llll}\text { Akuntansi } & 9 & \text { (1): }\end{array}$
https://doi.org/10.15408/akt.v9i1.3589.

D. Udiyanti, Ni Luh Nyoman ari, Anantawikrama Tungga Atmadja, and Nyoman ari surya Darmawan. 2014. "Pengaruh Penerapan Standar Akuntansi Pemerintahan, Sistem Pengendalian Internal, Dan Kompetensi Staf Akuntansi 
Terhadap Kualitas Laporan Keuangan Pemerintah Daerah (Studi Kasus Pada SKPD Kabupaten Buleleng)." E-Journal S1 Ak Universitas Pendidikan Ganesha 2 (1): 1-11. https://ejournal.undiksha.ac.id/index.php/S1ak/ar ticle/view/2978.

E. Herawati, Tuti. 2014. "Pengaruh Sistem Pengendalian Intern Terhadap Kualitas Laporan Keuangan (Survei Pada Organisasi Perangkat Daerah Pemda Cianjur)." STAR: Study \& Accounting Research 11 (1): 1-14. http://stiestembi.ac.id/file/1. Tuti Herawati (STAR Vol XI, No 1 - 2014).pdf.

F. Budiawan, Desiana Anugrah, and Budi S. Purnomo. 2014. "Pengaruh Sistem Pengendalian Internal Dan Kekuatan Koersif Terhadap Kualitas Laporan Keuangan Pemerintah Daerah (Studi Pada Pemerintah Daerah Kabupaten/Kota Di Wilayah I Bogor Provinsi Jawa Barat).” Jurnal Riset Akuntansi Dan Keuangan 2 (1): 276-88. https://doi.org/10.17509/jrak.v2i1.6581.

G. Sudiarianti, Ni Made, I Gusti Ketut Agung Ulupui, and I G.A. Budiasih. 2015. "Pengaruh Kompetensi Sumber Daya Manusia Pada Penerapan Sistem Pengendalian Intern Pemerintah Dan Standar Akuntansi Pemerintah Serta Implikasinya Pada Kualitas Laporan Keuangan Pemerintah Daerah." Simposium Nasional Akuntansi XVII 4 (71): 1-25. http://lib.ibs.ac.id/materi/Prosiding/SNA XVIII/makalah/117.pdf.

H. Faishol, Ahmad. 2016. "Pengaruh Sistem Pengendalian Intern Terhadap Kualitas Laporan Keuangan (Studi Kasus Pada Satuan Kerja Perangkat Daerah Pemerintah Kabupaten Lamongan)." Jurnal Penelitian Ekonomi Dan Akuntansi $\quad 1 \quad$ (3): 205-12. http://jurnalekonomi.unisla.ac.id/index.php/jpens i/article/view/85.

I. Kiranayanti, Ida Ayu Enny, and Ni Made Adi Erawati. 2016. "Pengaruh Sumber Daya Manusia, Sistem Pengendalian Intern, Pemahaman Basis Akrual Terhadap Kualitas Laporan Keuangan Daerah.” E-Jurnal Akuntansi Universitas
Udayana $\quad 16 \quad$ (2): $1290-1318$. https://ojs.unud.ac.id/index.php/Akuntansi/articl e/view/18075.

J. Mokoginta, Novtania, Linda Lambey, and Winston Pontoh. 2017. "Pengaruh Sistem Pengendalian Intern Dan Prinsip Pengelolaan Keuangan Daerah Terhadap Kualitas Laporan Keuangan Pada Pemerintah." Jurnal Riset Akuntansi Going Concern 12 (2): 874-90. https://doi.org/10.32400/gc.12.2.18282.2017.

K. Chodijah, Siti, and Nurul Hidayah. 2018. "Pengaruh Pemanfaatan Teknologi Informasi Dan Sistem Pengendalian Internal Terhadap Kualitas Pelaporan Keuangan Pemerintah Daerah (Studi Kasus SKPD Provinsi DKI Jakarta).” TEKUN: Jurnal Telaah Akuntansi Dan Bisnis 9 (1): 34-48. https://doi.org/10.22441/tekun.v8i1.2595.

L. Rahmawati, Astika, I Wayan Mustika, and Lilik Handaya Eka. 2018. "Pengaruh Penerapan Standar Akuntansi Pemerintah, Pemanfaatan Teknologi Informasi, Dan Sistem Pengendalian Intern Terhadap Kualitas Laporan Keuangan SKPD Kota Tangerang Selatan." Jurnal Ekonomi, Bisnis, Dan Akuntansi (JEBA) 20 (2): 8-17. http://jp.feb.unsoed.ac.id/index.php/jeba/article/v iew/1097.

M. Dariana, Dariana, and Jonase Oktavia. 2018. "Pengaruh Penerapan Standar Akuntansi Pemerintahan, Sistem Pengendalian Internal, Dan Kompetensi Staf Akuntansi Terhadap Kualitas Laporan Keuangan: Studi Kasus Pada Satuan Organisasi Perangkat Daerah Kab. Bengkalis.” JAS (Jurnal Akuntansi Syariah) 2 (1): 77-105. https://ejournal.stiesyariahbengkalis.ac.id/index. php/jas/article/view/132.

N. Purbasari, Heppy, and Andy Dwi Bayu Bawono. 2017. "Pengaruh Desentralisasi Fiskal, Sistem Pengendalian Internal Dan Kinerja Pemerintah Daerah Terhadap Akuntabilitas Laporan Keuangan." Riset Akuntansi Dan Keuangan $\begin{array}{llll}\text { Indonesia } & 2 & \text { (2): }\end{array}$ https://doi.org/10.23917/reaksi.v2i2.4884.

O. Karmila, Karmila, and Decky Hendarsyah. 2019. 
"Pengaruh Sistem Informasi Akuntansi Retribusi Boarding Pass Pelabuhan Terhadap Sistem Pengendalian Internal: Studi Pada PT. Pelabuhan Indonesia I (Persero) Cabang Dumai." JAS (Jurnal Akuntansi Syariah) 3 (2): 158-73. https://doi.org/10.46367/jas.v3i2.180.

P. Putri, Wahyu Syintia, and Decky Hendarsyah. 2020. "Pengaruh Sistem Pengendalian Internal Terhadap Penerapan Sistem Komputerisasi Haji Terpadu (SISKOHAT): Studi Pada Kantor Kementerian Agama Kabupaten Bengkalis." Inovbiz: Jurnal Inovasi Bisnis 8 (1): 52. https://doi.org/10.35314/inovbiz.v8i1.1252.

Q. Dewi, P Ayu Ratna, and Ni Putu Sri Harta Mimba. 2014. "Pengaruh Efektivitas Penerapan Sistem Informasi Pengelolaan Keuangan Daerah (SIPKD) Pada Kualitas Laporan Keuangan Di Pemerintah Kota Denpasar.” E-Jurnal Akuntansi Universitas $\begin{array}{llll}\text { Udayana } & 8 & \text { (3): }\end{array}$ https://ojs.unud.ac.id/index.php/Akuntansi/articl e/view/8252.

R. Yusup, Maulana. 2016. "Pengaruh Sistem Informasi Pengelolaan Keuangan Daerah Terhadap Kualitas Laporan Keuangan.” Jurnal Ekonomi, Bisnis \& Entrepreneurship 10 (2): 149-60.

http://jurnal.stiepas.ac.id/index.php/jebe/article/v iew/155.

S. Pirade, Dominggus, A. Karim Saleh, and Muhammad Yunus Amar. 2013. "Pengaruh Penggunaan Sistem Informasi Pengelolaan Keuangan Daerah (SIPKD) Terhadap Kinerja Pegawai Di Kabupaten Tana Toraja." Jurnal $\begin{array}{llll}\text { Analisis } & 2 & \text { (2): } & \text { 183-92. }\end{array}$ http://pasca.unhas.ac.id/jurnal/files/474d0391133 181c7011cf2cb812585de.pdf.

T. Wicaksono, Ready, and Mispiyanti. 2019. "Pemanfaatan Sistem Informasi Pengelolaan Keuangan Daerah (SIPKD) Pada Aparatur Pemerintah Daerah.” InFestasi: Jurnal Bisnis Dan Akuntansi $15 \quad$ (2): 177-90. https://journal.trunojoyo.ac.id/infestasi/article/vi ew/6007.

U. Mahendra, Aldillah Reza, and Didied Poernawan
Affandy. 2013. "Faktor-Faktor Yang Mempengaruhi Minat Pemanfaatan Sistem Informasi Pengelola Keuangan Daerah (SIPKD): Studi Kasus Pada Pemerintah Kota Blitar.” Jurnal Ilmiah Mahasiswa FEB Universitas BRawijaya 1 (2): https://jimfeb.ub.ac.id/index.php/jimfeb/article/v iew/317.

V. Sutanto, Sutanto, Imam Ghozali, and Rr. Sri Handayani. 2018. "Faktor-Faktor Yang Memengaruhi Penerimaan Dan Penggunaan Sistem Informasi Pengelolaan Keuangan Daerah (SIPKD) Dalam Perspektif the Unified Theory of Acceptance and Use of Technology 2 (Utaut 2) Di Kabupaten Semarang." Jurnal Akuntansi Dan Auditing $\quad 15 \quad$ (1): $\quad 37-68$. https://doi.org/10.14710/jaa.15.1.37-68.

W. Dwiyanti, Rini. 2010. “Analisis Faktor-Faktor Yang Mempengaruhi Ketepatan Waktu Pelaporan Keuangan Pada Perusahaan Manufaktur Yang Terdaftar Di Bursa Efek Indonesia.” EPrints Undip. Universitas Diponegoro. http://eprints.undip.ac.id/22634/.

X. Kadir, Abdul. 2011. "Faktor-Faktor Yang Berpengaruh Terhadap Ketepatan Waktu Pelaporan Keuangan: Studi Empiris Di Bursa Efek Jakarta.” Jurnal Manajemen Dan Akuntansi 12

$1-12$. http://journal.stiei-kayutangi-bjm.ac.id/index.php /jma/article/view/24.

Y. Hastutik, Suci. 2015. "Pengaruh Profitabilitas, Likuiditas, Struktur Kepemilikan, Ukuran Perusahaan Dan Opini Audit Terhadap Ketepatan Waktu Pelaporan Keuangan Perusahaan.” Jurnal Akuntansi Dan Sistem Teknologi Informasi 1 (Khusus):

102-11. http://ejurnal.unisri.ac.id/index.php/Akuntansi/ar ticle/view/1054.

Z. Budiyanto, Sarwono, and Elma Muncar Aditya. 2015. "Faktor-Faktor Yang Memengaruhi Ketepatan Waktu Pelaporan Keuangan: Studi Empiris Perusahaan Food and Beverages Periode 2010-2012." Fokus Ekonomi 10 (1): 77-87. https://ejournal.stiepena.ac.id/index.php/fe/articl 
e/view/74.

AA. Momuat, Chandra Putra Immanuel. 2016. "Pengaruh Pemanfaatan Teknologi Informasi Terhadap Ketepatan Waktu Pelaporan Keuangan Dalam Rangka Mewujudkan Transparansi Dan Akuntabilitas (Studi Pada Kabupaten Minahasa Tenggara)." EMBA: Jurnal Riset Ekonomi, Manajemen, Bisnis Dan Akuntansi 4 (1): 1519-30.

https://ejournal.unsrat.ac.id/index.php/emba/artic le/view/12373.

BB. Sanjaya, I Made Dwi Marta, and Ni Gusti Putu Wirawati. 2016. "Analisis Faktor-Faktor Yang Mempengaruhi Ketepatan Waktu Pelaporan Keuangan Pada Perusahaan Manufaktur Yang Terdaftar Di BEI.” E-Jurnal Akuntansi Universitas Udayana 15 (1): 17-26. https://ojs.unud.ac.id/index.php/Akuntansi/articl e/view/15057.

CC. Feriyanto, O, and Encep Hadian. 2014. "Sistem Informasi Akuntansi Pengeluaran Kas Dan Pengendalian Intern Pengeluaran Kas: Studi Deskriptif Pada UKM Di Kota Bandung.” STAR Study \& Accounting Research 11 (1): 68-75. http://journal.stembi.ac.id/medias/journal/5._O._ Feriyanto_Encep_Hadian_STAR_Vol_XI_N o_1_-_2014_.pdf.

DD. Driteny, Rela. 2010. "Gambaran Umum Tentang Sistem Pengendalian Intern Pemerintah.” Forum
Manajemen 2
74-81.

http://pusdiklatmigas.esdm.go.id/new/lsp/file/m1 --_Gambaran_Umum_---_Rela_Driteny.pdf.

EE. Rai, I Gusti Agung. 2010. Audit Kinerja Pada Sektor Publik. Jakarta: Selemba Empat.

FF. Presiden RI. 2008. "Peraturan Pemerintah Republik Indonesia Nomor 60 Tahun 2008 Tentang Sistem Pengendalian Intern Pemerintah.” Jakarta: Pemerintah Republik Indonesia.

http://www.bpkp.go.id/public/upload/unit/sakd/fi les/PP60Tahun2008_SPIP.pdf.

GG. Kemendagri. 2006. "Permendagri Nomor 13 Tahun 2006, Tentang Pedoman Pengelolaan Keuangan Daerah.” Jakarta.
HH. Rama, Dasaratha V., and Frederick L. Jones. 2008. Sistem Informasi Akuntansi (Accounting Information System). Jakarta: Salemba Empat.

II. Dadang, Suwanda. 2014. Kebijakan Akuntansi Berbasis Akrual Berpedoman Pada SAP. Bandung: PT. Remaja Rosdakarya.

JJ. Umer, Chapra, and Tariqullah Khan. 2008. Regulasi Dan Pengawasan Bank Syariah. Jakarta: Bumi Aksara.

KK. Wasilah, Sri Nurhayati. 2015. Akuntansi Syari'ah Di Indonesia. Jakarta: Salemba Empat.

LL. Bupati Bengkalis. 2016. "Peraturan Bupati Bengkalis Nomor 67 Tahun 2016 Tentang Kedudukan, Susunan Orgnisasi, Eselonering, Tugas Dan Tata Kerja Pada Staf Ahli Bupati Bengkalis.” Bengkalis: Pemerintah Kabupaten Bengkalis. 